\title{
Japan's priorities in Taiwan: Its impacts on Japanese relations with America and China
}

\author{
Sahibzada Muhammad Usman*1-2 | Yamama Khalid ${ }^{3}$ \\ 1. Department of Aerospace Science \& Strategic Studies, Air University, Islamabad, Pakistan. \\ 2. Department of Political Sciences, University of Pisa, Italy. \\ 3. Department of Political and International Sciences, University of Siena, Italy. \\ *Correspondence Emails: s.usman@ @studenti.unipi.it | sahibzada.usman@ mail.au.edu.pk
}

\begin{abstract}
America-Japan partnership is now at the core of the America-led defence system in the East Asia. The unresolved state of Taiwan is already one of the worst security conditions in the region in the terms of this partnership. It may contribute to a big confrontation of one or both countries with China. The broader Taiwan-Japan-China-America ties usually regard Taiwan and Japan as the least influential combination imaginable. Despite this fact, the depth of engagement, hard to categorize and with great potential to affect stability and security in the field, is reversed from this tertiary regional connection. Therefore, Japan's major goal to balance the power with Taiwan is to preserve and develop constructive de-facto state-to-state ties between the liberal and democratic powers of similar consciousness, both of which are scared of the Chinese control. This paper discusses the specific ties between Japan and Taiwan in conjunction with Japanese domestic priorities and analyses the repercussions for America-Japan cooperation in the future. Especially about Japan, the American and Taiwanese governments should identify areas of difference early on and resolve emerging issues within the alliance's auspices.
\end{abstract}

Article History

Received:

July 15,2021

Revised:

August 15, 2021

Re-revised:

September 27, 2021

Accepted:

October 26, 2021

Published:

November 3, 2021

Keywords: Japan-Taiwan relations, US-Japan relations, China-Japan relations, US-China relations, US-Taiwan relations, China-Taiwan relations, geopolitics of Taiwan strait.

How to Cite: Usman, S. M. \& Khalid, Y. (2021). Japan's priorities in Taiwan: Its impacts on Japanese relations with America and China. Liberal Arts and Social Sciences International Journal (LASSIJ), 5(2), 222-235. https://doi.org/10.47264/idea.lassij/5.2.15

Publisher's Note: IDEA PUBLISHERS (IDEA Publications Group) stands neutral with regard to the jurisdictional claims in the published maps and the institutional affiliations.

Copyright: (C) 2021 The Author(s), published by IDEA PUBLISHERS (IDEA Publications Group).

Licensing: This is an Open Access article published under the Creative Commons AttributionNonCommercial 4.0 International License (http://creativecommons.org/licenses/by-nc/4.0/) 


\section{Introduction}

America-Japan partnership is the backbone of East Asia's America-led defence systems, which have carried to the present day of the region's basic balance of force. Taiwan's unresolved state poses one of the region's most dangerous security conditions and may contribute to war with China within this coalition's terms. The Japan-Taiwan alliance is commonly regarded to be the least prevalent of all potential combinations within the broader spectrum of ties between Taiwan, Japan, China, and America Taiwan and Japan ought to be formed not to sustain certified state-to-state ties, and, unlike America, Japan does not have the constitutional authority to notify its relationship with Taiwan. Instead of that, the complexity of contact, difficult to define, is exposed when the casual veneer is stripped from this tertiary regional Partnership. Although Taiwan could be a big threat and rationale of America-Japanese alliance for military and commentator's planners, this will be a substantial oversimplification of how Japanese evaluate the Taiwanese problem. Similarly, China-America link statements usually see Japanese citizens' presence in the Taiwan problem as a destabilizing force rather than a significant regional partner with a special perspective and possible influence for Taiwan ties. Many on American foreign policy could be surprised by Taiwan's argument that it is "Japan's problem" since, for the past 60 years, America has been the biggest guarantor of stability in the Taiwan Strait (Hisahiko, 2005).

Taiwan's citizens and the government may struggle with island homes being seen as a problem first and worrying that it will be a problem for another country. It should be recognized that Japan has a separate geopolitical view of Taiwan. Given America participation, the placement of army forces, and the region's recent rebalancing policy classification, all of which Okazaki strongly supports - America is still an external player on a regional geography-driven issue. In brief, America doesn't exist in the community of East Asia, but the stakes for America necessarily vary from those of regional actors. The common background, language, culture, bureaucratic and economic growth of institutions, and mutual respect for pragmatism and order are important factors that have helped Japan sustain a profound partnership and serve its interests in Taiwan. An inference that can be focused on the essence of Japan's ties with Taiwan is that America is more invested and vulnerable to fostering the Taiwanese Strait's reconciliation. Another fundamental truth that should not be underpinned is the considerable weakness of Japan's relationship with Taiwan and its participation in the Taiwan Strait settlement. At many periods in history, Japan's fundamental ambitions in Taiwan have been overwhelmed by China's aspirations and pressure or America.

The 24 million Taiwanese could not be dismissed for their right of self-determination. During this close climate, Japan's benefits in Taiwan have complemented or converged the American interests in large numbers. Japan and China also found an implicit degree of agreement regarding Japan's partnership with Taiwan over the years. Now, Japan has developed a position in Taiwan as a proactive economic partner and a passive balance for China's rising power in Taiwan (Khatoon et al., 2018; Matsuda, 2012). An intriguing next issue is, can Japan be a Taiwan balancer rather than a passive one? Simultaneously, their common political philosophy strengthened the Taiwan's connections and supplemented the mutually advantageous economic relationships, which persisted even after the broken formal ties. Taiwan has been an example of a successful East Asian industrialized economy that shares features of the progressive state, of which Japan was a leader. The democratic transition under the Lee-Teng-hui Presidency strengthened its ties. It was inevitable that Japan would begin to reassess the possibility of extending its relations with Taiwan with democratic peace theory. The study focuses on two 
main questions as: (a) what are the national priorities of Japan in Taiwan, and how have they been applied in the past of interaction? and (b) what are the repercussions for the AmericaJapan partnership of Japan's lasting and existing ambitions in Taiwan?

\section{Literature review}

The Taiwanese people were considerably more prepared to accept Japanese authority, although they did not remove a first colonial invasion, usually a chaotic attempt. Japan first sought control of Taiwan, "not more or less brutal than the typical colonial camp" and Qing authorities declared instant opposition to Taiwan as the "Republic of Formosa" in 1895 (Asahi, 2013). Nevertheless, particular people have important, enduring effects, as with the rest of JapanTaiwan ties. Goto Shinpei, head of home affairs for Taiwan in 1896-18, is still a significant character in the Japanese colonial narrative. In the first decade of Japanese control, Goto was the main architect behind the rapid change of Taiwan from a "prejudice into a colonial showpiece" (Mark \& Ramon, 1984, p. 19).

Goto's colonial philosophy included a detailed scientific approach based on the extensive sociological study and the successful implementation of colonial programmes that are wellplanned and organized. These measures included the progressive elimination of opium and the first accurate census and land survey, making taxes easier. During Goto's reign, currency, weights and measurements were standardized. The economic infrastructure, including new trains from Keelung's major northern port to Kaoshiung's Southern Port, modern port facilities and power plants, was perhaps the most significant material accomplishment in the Japanese reign (Douglas, 1970, pp. 16-18). Under the Japanese colonial authority, overall economic production would grow three times the population over the same period. Taiwan, a previously unknown Qing Dynasty province, had been transformed into a modern, economically independent, profit-driven agricultural producer in 1918 (Copper, 1999, p. 129). This farm was important to Japan's bigger goals in the area (Mark \& Ramon, 1984).

While much of the Taiwanese colony literature focuses on the cultural efficiency of Japanese personalities and governance such as Goto, in the "Taiwan in Japan's Empire building" book of Ts'ai (2009), in the recent technical studies, Japanese colonial rule methods such as social engineering, institutionalization, colonial mobilization during the second world war, and the heritage left behind are discussed. Ts'ai presents a complex image of an ad-hoc Japanese method that developed with Taiwan's organic growth, but its origins were in Meiji Japan's simultaneous development and upgrading experience. In addition, the Japanese handled the colonial government of Taiwan by integrating indigenous social forces only, when possible, in this learning process. In addition, it emphasizes that the scope of every village and town in Taiwan was accurately defined by carrying out a comprehensive land survey, including any large field, planting, and significant production capacity. Although Japanese experts mostly gathered information inside the central office, the government selected Taiwanese local leaders as survey commissioners. According to the balance between central supervision of the arable land and local administration, accuracy was stimulated, and the net effect was improved production efficiency and taxes (Ts'ai, 2009).

There should not be ignored the bad elements of the Japanese control in Taiwan. Almost in every tangible aspect for the Japanese, Taiwan government may be considered effective, yet it has failed to attain genuine devotion to the Taiwanese people. Negative comments about Samurai's leadership style have criticized him, while efficient for administration and 
productivity, as the authoritarian Samurai of the same order that is to be found in the classical Chinese legalist literature, the Book of Lord Shang and his aims at regular social obedience. Even in the 1960s, a "period of dogs" was often referred to as the Japanese Colonial rule in Taipei streets (George, 1974).

\section{Research methodology}

The core techniques for this analysis are qualitative. Information comes from blogs, books, newspapers, and government websites. The strategies for developing foreign policy will be discussed by explaining internal and external influences on policy implementation. There will also be a review of particular strategies, programs, and activities underway, which accomplish or protect certain interests. The Yoshida Doctrine, sometimes called the " 1955 system", would be the foundation for Japan's new foreign policy and almost 30 years following WWII, the MITI would supply the central bureaucracy (Green, 2002, pp. 565-573). Each period begins with a historical survey of critical junctures and concludes with an attempt to extract Japan's main interests in Taiwan in terms of foreign-policy methods used to accomplish those goals, and a judgement on outcomes, including a comparison to the United States' interests in Taiwan over the same period.

\section{Japan-Taiwan relations vis-à-vis Chines and American interests: a discussion}

\subsection{Past of ties between Japan and Taiwan}

Japan is Taiwan's second important and close nation in the world behind America. For this, there are several explanations: (a) the two nations are similar to each other geographically; (b) for fifty years, Japan had been the colonial master of Taiwan; (c) Japan is a big democracy in Asia; (d) the two countries have extensive bilateral exchange and investment. After the democratization of Taiwan, Japan-Taiwan relations have been much stronger. The Manchus moved Taiwan towards Japan after the Manchu-Japan War. It was a chance to modernize Japan to convince the Western powers that Japan might become a powerful imperial force. Japanese propaganda highlighted Taiwan as a model colony and Taiwanese as Japanese, but the fact was that Japanese rule was very harsh in Taiwan. But as Kuomintang was almost as brutal but even more dishonest under the Chiang Kaik, Taiwanese started to look at Japan as better as it was. Taiwan's feelings for Japan were also reasonably strong. In 1945, when the Kuomintang controlled Taiwan under Chiang Kai-shek, things soon declined in Taiwan. However, in the post-colonial era, ties with Japan were about to improve positively. In the Second World War, the Chinese opposed the Japanese. Chiang Kaishek's demand was mild, culminating in collaboration between Taiwan and Japan during Chiang Kai-reign. Among the international officials with whom Taiwan officials most often interacted were Japanese and American ambassadors in Taiwan. The double representation motion collapsed, and Taiwan finally quit the UN in 1971 because of Chiang Kai-stubbornness (Jacobs, 2006).

In 1972, when Japan recognized Pekin, China's claim to Taiwan was dismissed. Also, Taiwan's unofficial relations with all other nations worldwide are set a precedent for the Japanese formula for formalizing non-official organizations to preserve unofficial ties between Taiwan and Japan. During World War II, Lee had trained in Japan and had a much greater knowledge of Japan than Chiang Ching-Kuo and Chiang Kai-shek. Thus, the Taiwanese's favourable perceptions of Japan helped to reinforce the relations. Furthermore, Taiwan democracy under Lee Teng-Presidency Hui's added a fresh understanding between the two countries and the 
traditional democratic principles. Under Chen Shui-leadership, Bian's strong relations persisted. Japan was the second nearest ally to Taiwan after America during the Chen and Lee Administrations. In the early days of President Ma Ying-tenure, Jeou's ties between Japan and Taiwan worsened. With his roots in Mainlander, and his ancestral animosity to Japan dated back to World War II, President Ma excluded Japan from his opening address and asserted the islands of the Senkaku. However, Taiwan's ties with Japan have strengthened significantly in few months, and the Ma government has made significant efforts (Jacobs, 2012, pp. 239-243). Moreover, Japan and Taiwan are significant economic allies and propinquity, imperial past, and mutual democratic principles. Japan is the second-biggest business partner in Taiwan, while Taiwan is the fourth biggest business partner in Japan. Both nations have understood handling the other country more favourably de facto (Ryo, 2014, p. 234). With over 3 million visitors in 2012, tourism has also improved relationships in the other nation with cultural exchanges, youth job structures on vacation, the academic exchange, and significant help for natural disasters (Jacobs, 2013).

\subsection{Geopolitical condition of Taiwan strait}

China has confirmed it is going to take Taiwan - if needed by coercion. Yet, it's not going to work. The price is not too high, and American and Japanese military participation are certainly not low on Taiwan's behalf. Tokyo either helps or sits down in Taipei and wishes that China will not govern Taiwan. If this is the above option, Japan could be well-positioned to veto Beijing's economic, political, diplomatic, and domestic policies. And Japan, beginning with the Senkaku Islands, will just have to surrender parts of its southern territories. In the centre of the sea channels, Taiwan occupies strategic geography from which much of Japan's oil source and exchange flux. Take Taiwan, and when it wishes, China will break them off. Forget of the South China Sea 'flying around.' China-controlled Taiwan would be a naval and air operations springboard in the middle of the Central Pacific for the People's Liberation Army. In the southwest island chain, Japan's southern defences are outsourced. The East China Sea-and the Senkakus - and finally a move to take over the Ryukyus expect tensions. And the consequences of the knock-on are almost as terrifying. Just in Southeast Asia and elsewhere, would Japan be interested in the misery of Beijing. As partners drawback under the Chinese pressure, Japan's regional power would decrease (Grant, 2020; Sheerazi et al., 2020).

Moreover, Taiwan's defeat would send a body blow to America's status and reputation in Asia. Smaller provincial nations can fight to comply with China as best they can (Grant, 2020). Maintaining Taiwan's de facto freedom is one of Japan's core security concerns, while China's continued military growth disrupts the balance of power in the Strait. But Japan's protection and security ties with Taiwan are not wise. However, that would be detrimental, in reality. Japan should instead respond to China's attempts to achieve coercive power through a considerable increase in interoperability with America and preserve its current sub-rosa communication rate with Taiwan's defence establishment, rather than sticking to the hornets' net and causing an emotional overreaction from the hypersensitive Chinese Communist Party. The leadership of China criticizes the administration's foreign sponsorship of Taiwan. Any transparent measures by Tokyo to protect Taipei would yield a reflective and neuralgic reaction. Because of clear anti-Japanese positions on the part of the leadership or because they would have to repress, punishing Japan at all expense in the people's view.

Beijing would be suffering significantly - political, economic, reputational cost - as shown by the attempt to discipline Seoul on THAAD radars' deployment. Imagine the degree to which 
the fragile matter of Taiwan causes a reaction. Some have suggested that because China is still pedalling into the metal of military growth, a defence dilemma in North-East Asia cannot be feared unless Japan is securely replaced. It underlines China's ability to step up or expedite its defence growth. A political mechanism with a wide spectrum of variables matched with each other benefits from the existing rate of rising military expenditure, whereas Japan's direct presence will rewrite the political equation within China. That is bad news for Japan which relies on America to defend itself. The days are over where Tokyo will depend on America to look after Taiwan. America is over-extended and wants support from Japan in Taiwan. Indeed, the more Japan benefits, the more apt America is to protect Japan. With or staggered by the Americans after the collapse of Taiwan, Japan would have to confront the nearly difficult challenge of creating a Japanese Self-Defence Army to control the Chinese army and use nuclear power (Benjamin, 2020).

\subsection{The next point regarding the ties between Japan and Taiwan}

Presidential Yuan elections in Taiwan, where strong historical, cultural, and social relations with Taiwan, have been closely watched in Japan. Japan's Foreign Ministry issued its official declaration congratulating Tsai Ing-wen for her victory and assuring that the Abe administration strengthens collaboration' with Taiwan. Further economic collaboration is Japan's strategic potential with Taiwan. The comments made by Secretary Yoshihide Suga on support for Taiwan's entry into the Trans-Pacific Partnership reflect a welcome move towards Tokyo-Taipei ties in 2016. There is a shared interest in improving the relations between Taiwan and Japan. Despite shortfalls in diplomatic relations, polls show that Japan remains Taiwan's most favoured nation, and 67\% of Japan's citizens have said they felt close to Taiwan in 2011. Japan is the second biggest trade partner in Taiwan on the economic front, though Taiwan is the fourth highest in Japan. Although the population is comparatively tiny, Japan has the thirdlargest number of tourists after China and South Korea.

Taiwanese reaction to the 2011 Great East Japan Earthquake has amply reflected these local relations. A total of 2,92 billion yen has been contributed, rendering Taiwan the world's secondlargest source of relief funds after America (Ayumi, 2016). However, Tokyo's ties with Seoul and Beijing have been influenced by the complicated historical difficulties and territorial conflicts between Taiwan and Japan. Taipei's view is that Tokyo and Beijing, which is the Taiwanese islands called Diaoyutai, have collided in the East China Seas and that the wartime treatment of Taiwanese women who have been compelled to take part in military brothels by imperial Japan remains a persistent frustration in Taiwan (Mark, 2015). The political interest of Tokyo and Taipei overshadowed any of the latent wounds of the past. In 2013, Taiwan and Japan finally concluded a long-sought-after fishing agreement under President Ma Ying-East Jeou's that allowed Taiwanese fishermen to operate in part of Japan as its Economic Zone and set a dispute settlement mechanism for fishers. The Japanese fishers remain angry regarding the fishing activities of Taiwanese trawlers. Still, this resolution has established a promising precedent for resolving the East China Sea's territorial conflicts (Tetsuo, 2015).

Recent Tokyo strains with Beijing have led some Diet Participants to promote a deeper connection with their Southern Democratic neighbour. Scholars have also called for Japan's ties with Taiwan to be elevated to reflect the evolving essence of Taiwanese and Chinese Heads' relations at the first-ever Summit in 2014 (Kawashima, 2015). Japan cannot just sit back and allow Taiwan's problems to be settled peacefully, as outlined in the MOFA declaration, through direct dialogue between the parties concerned. Instead, the Abe cabinet can see what it can do 
to ensure the strongest outcomes in its constructive commitment to stability. But Japan's direct support of Taiwan's defence, as reported in Japan's Taiwan Relations Act, can only threaten Tokyo's relations with Beijing, triggering needless tensions between Taipei and Beijing. Rather, by more economic collaboration with Taiwan, Japan can follow its geopolitical interests. One clear first move will inspire Taiwan to participate in the TPP, as Tsai called for during her Japanese tenure. Suga's declaration was a welcome move in this path, and Japan needs to collaborate with America and other TPP parties to gain support and encouragement for Taiwan's inclusion. The TPP is a high-standard free-trade program available to all member economies, including Chinese Taipei, of the Asia Pacific International Cooperation Forum. Ensuring Taiwan's economic dynamism and encouraging regional economic cooperation will improve relations with Taiwan and show Japan's ability to cooperate with citizens dedicated to peaceful conflict settlement in the Asia-Pacific region (Kawashima, 2015).

\subsection{Ties between China and Taiwan}

Taiwan is an island off China's southern coast that has been administered separately from mainland China since 1949, formally recognized as the Republic of China. Political leaders disagree about the Island's condition and its links to the continent of Taiwan, a region of 23 million citizens with its own free elected government. Trade ties between the Island and continental countries have thrived since the jurisdiction dispute of recent years. However, the partnership is shadowed by diplomatic friction, and new leadership strains have revived Taiwan and China. The position of the Island is deeply split between Taipei and Beijing. China claims there is "one China," and Taiwan is a member of that. Peking says Taiwan is linked to a 1992 agreement between the Kuomintang and the Communist Party of China (Lawrence \& Morrison, 2017). The 1992 Consensus notes that only one China is available but that there are varying interpretations that, according to Taipei and Beijing, render Taiwan a Chinese state, while the two disagree on the Chinese's rightful governing body. Taiwan should not look for liberation, as is the implicit agreement behind the 1992 Consensus. KMT still agrees upon the consensus as a starting point for potential talks with the CCP from Taiwan.

However, the new President of the Island, Tsai Ing-wen, chief of the Democratic Progressive Party, opposed the consensus. She proclaimed the structure 'one nation, two systems' suggested by Beijing unreasonable during a speech in 2019. She and other leaders in the ruling DPP oppose the consensus and open up the prospect of future Taiwanese democracy. By concluding a joint communiqué in 1979, America formed official diplomatic ties with Beijing. America recognized China's status, namely that only China and Taiwan were part of China. American President Jimmy Carter ended the ROC government's diplomatic ties in Taiwan. Congress enacted the Taiwan Relations Act (TRA), affirming significant informal links to the Island. It provides for self-defending weapons sales to Taiwan, which does not preclude America from standing up for Taiwan against the Chinese attack - a tactic called strategic uncertainty. Since then, shipments of American weapons to Taywan also contributed to increased war-fighting rhetoric in the Strait, totalling more than 25 billion dollars in 2018 (Lawrence \& Morrison, 2017, 2017). The Trump administration also appears to be expanding its ties to Taiwan on Chinese objections, offering numerous weapons arrangements and announcing its de facto embassy in Taipei with a $\$ 250$ million complex (Lindsay, 2019).

After the 2016 vote, the revolt against the ruling KMT in exit polls posed concerns about social viewpoints about Beijing's relations. A Taiwanese rebellion against the ROC led by KMT, which in 1947 was violently crushed, as the foundation of a powerful Taiwanese ethnic identity 
that seeded democracy. The Taiwanese citizens and the police seem to have linked centuries of political traditions together. Although most of the citizens in the Strait of Taiwan talk their first language, an increasing number of Taiwanese speak Mandarin for more than a century in separation and believe that they earn the freedom to live separately. According to a 2018 National Chengchi University report, almost 55 per cent of the island inhabitants considered themselves solely Taiwanese. By contrast, $38 \%$ were Chinese and Taiwanese, down from $43 \%$ in 2008, although about 4\% were Chinese. In a 2016 article for the Asian Society, Anna Beth Keim wrote that the civic revolution of youth in Taiwan had been motivated by realistic grievances and political values. A surge of domestic political activities - often referred to as the Third power of Taiwan-induced frustrations regarding Taiwan's financial inequality and discontent with the political groups (Lindsay, 2019).

In the meantime, the $\mathrm{Xi}$ from China has stressed the need for Taiwan to stick to One China's concept. He said Taiwan must be integrated with the mainland and that there is no hindrance to integration in the various structures of the Island. Experts from China assert that Taiwan's election of pro-autonomy leaders in terms of the security issues could move Beijing to protect territorial integrity across the Taiwan Strait from territorial disputes on the South and East China Seas. In 2020, Tsai's landslide re-election was perceived as a rebuke to Peking by observers who sought to affect the vote in favour of the challenger. CFR-based Joshua Kurlantzick writes that Tsai's victory combined with more detailed linkages between America and Taiwan will render China-Taiwan one of the most strained ties in recent years. While the major political parties in Taiwan disagree about how the Island's interactions with Beijing should be better administered, analysts warn that the blame for preventing conflicts would rest with Taipei and Beijing. CFR President Richard wrote that the status quo is imperfect but much less flawed than unilateral interventions would be accompanied by efforts to remedy an unpurposed condition (Eleanor, 2020).

\subsection{America is seeking to strengthen the position of Taiwan}

The Trump Administration has improved ties between America and Taiwan's democratic Island and strengthens its diplomatic position. These initiatives are intended to showcase a stable democracy in Asia and fight Chinese efforts to undermine Taiwan's foreign diplomatic position. It is a feeding stock to a larger national safety campaign: putting America on a longperiod path of rivalry and conflict with China, which would be hard on every American president, whether Republican or Democrat, in the future (Edward \& Steven, 2020). Mr Colby has published the National Security Policy of the Trump Administration, stressing rivalry with Russia and China (Jim, 2020). For seven decades, Taiwan has become a fierce dilemma for Beijing and Washington. As national security officers drive their campaigns toward China, it reappears as a likely focal point of the tensions. The officials also see Taiwan being improved more urgently in the face of the Chinese Communist Party chief Xi Jinping's assault on human rights in Hong Kong. Trump himself admires $\mathrm{Mr} \mathrm{Xi}$ and is particularly dyspeptic about Taiwan. In his latest book, the former advisor on national security, John Bolton, once contrasted with Sharpie markers and China as Resolute Desk (John, 2019). And the President is prepared to sacrifice America help for China for trade ties with the democratic nation, he said. President Richard Nixon initiated the negotiating process with Communist China in 1971 to gain Mao Zedong's support in countering the Soviet Union. America established diplomatic ties with China in 1979, then split formal relations with Taiwan, a haven for the Chinese Kuomintang, or nationalists, 30 years ago (Bonnie, 2017; Mukhtar et al., 2020). 
Every American government, which is focused on a one-China strategy, has tried to retain an unclear stance on Taiwan. The uncertainty has helped keep the Taiwan Strait one of the most militarized regions globally. But as China has become greater and more assertive, and $\mathrm{Mr}$ Trump's "America First" foreign policy has started undermining diplomatic commitments, American officials and policy analysts from Washington argue that America's conventional approach to Taiwan benefits tough liners in Beek and boosts the danger to China's Island 24 million (Edward, 2019). Along with Democratic and Republican politicians, these authorities are dedicated to America support for Taiwan as far as they can. They intend to give China military messages and make Taiwan similar nation-to-nation until sovereignty is recognized. While Bolton is very much in favour of full diplomatic ties, several American officials, including some Chinese hawks, were hesitant, afraid of such a change being a total split with Beijing (Chan, 2020).

The American officials convinced President Trump to sign the bipartisan Congress Taipei Act, which promises Washington to help Taiwan boost its foreign image and condemn the so-called China intimidation strategies of the bill's sponsors Senate. The White House openly denounced China's efforts in Orwellian foolishly pressuring American businesses, hotels and airlines, to talk Taiwan. Some officials debated sending Taiwanese Mandarin Chinese teachers to America to get American schools to sever ties with Confucius Institutes operated in Beijing. American officials declined to secure Taiwan Observer Status for China in an assembly of the World Health Organisation (Andrew \& Michael, 2020). Taiwan Relations Act of 1979 is a key feature of America-Taiwan links, forcing Washington to sell defensive arms to Taiwan. It was adhered to by Constitutional and Conservative regimes. Bolton donated two massive packages: an 8billion-dollar sale of F-16 fighter jets and a 2.2 trillion-dollar sale of Abrams. The government told Congress of a proposal to export advanced torpedoes worth $\$ 180$ million (Joseph, 2020). Some officials complain that weapons sales are not as strong as Washington and increased transit via Taiwan by American warships. They told Beijing and Taipei that Washington would secure Taiwan if the PLA attempted an attack or a blockade. It is not protected in the Taiwan Ties Act, which has been ambiguous in previous administrations (Edward, 2020).

The $21^{\text {st }}$ Century's international system will be based entirely on how well countries do. Nationalism will be judged on which nations' ability to unleash the capabilities of their people, spur innovation, and provide answers to global problems is taken into consideration. The use of skill and technology will measure national strength. As long as Taiwan and America are allies, they should do so. Enlarging educational exchanges and collaborating on technical innovation will yield strategic benefits and trans-fertilise investments in vital technology development. Joint efforts to speed up the development and implementation of green technologies will have the same effect. America Taiwan-America cooperation may also help improve democracy's resistance to outside meddling. Taiwan and America have new opportunities to strengthen their mutually beneficial cooperation now that American foreign policy is transitioning. It's in the best interests of both parties to take advantage of such possibilities (Ryan, 2021).

\subsection{Japan and America partnership implication}

America is the greatest economic and maritime force globally; Japan is the largest maritime democracy in Asia and the second-largest capitalist society in America. America is now focused on the confluence of the Indian and Pacific oceans. Japan would become more critical than ever before for the relations between Japan and America's other allies and partners. 
President Nixon laid down five criteria for negotiating normalization with China in 1972 (Kan $\&$ Morrison, 2014). The Partnership has faced various obstacles, and it remains the cornerstone of the America-led defence system in East Asia. Taiwan's unresolved state is now one of the region's most volatile security circumstances, which may contribute to a major war with China beyond this coalition's boundaries. The broader Taiwan-Japan-China-America ties usually regard Taiwan and Japan as the least influential combination imaginable. Despite this fact, the depth of interaction that is challenging to categorize is hard to reverse. However, it can have a major impact on stability and security in the region. While America bears a more formal obligation for Taiwan, as illustrated in the TRA, focused on Japan's rich collaboration with Taiwan. Japan's great policy to foster relations with like-minded nations is likely to be codified, with a powerful Taiwan lobby being embraced by the public.

Taiwan has more formal obligations in case its convergence with China is growing or even effective. In that case, Japan's core interests in Taiwan could vary dramatically from American interests, and considerable cooperation is needed for the alliance to handle such differences. Specifically, if America policy against Taiwan and China is problematic or America approach in the area may be improved by the fact that Japan has a more powerful interest than America in Taiwan, independent of the mechanism of unification, based on a broad range of factors and strategies utilized by the cooperation. Moreover, in the triangular ties with Japan, America and Taiwan could play a more assertive position as a passive balance sheet and constructive in Taiwan's growing dependence on China. Specifically, Japan could provide Taiwan with diplomatic space with America bordering on more contentious cross-cutting topics like weapons purchases. Although a Japan-Taiwan structured security agreement will pose a great challenge and danger to Japan-China ambitions, current developments suggest it is not fully beyond the domain. To a certain degree, Japan might give China a nonmilitary balance, usable for America's conventional position, providing Taiwan with diplomatic room in negotiations with China to reach an appropriate outcome. Japan could enable America to facilitate the Partnership in other more challenging ways, such as the base and practical self-defence structures in areas across Japan and beyond. America may not need to make any political efforts to reassure Japan of the value of tackling China by helping Taiwan. However, it will have to persuade Japan that Taiwan's funding is in the interests of America (Auer, 2013, p. 7).

As the geopolitical condition begins to shift, Japan could end up telling America that the Taiwan's assistance lies in both countries' lasting interests. Behind the closed doors must take place a vital part of the essential role of the coalition leaders. James Auer remains an optimist about the sustained prosperity and peace in the region as part of the joint America-Japan initiative to establish a shared policy to prevent the Chinese aggression. He believes that although China's growth is undeniable and cynical of its present and potential actions, improved coordination between Japan and America would help meet the issue. The SDFs in Japan must become more operational and freer of prohibitions to combine defence, particularly in Japan's southwest territories. Although the duality of a hail and engagement approach to China confuses many people in America and Japan and concentrates many others on the strategic air-sea combat concept, Auer stated T.X.'s strategy for the offshore control is emerging. Overall, the policy that promises the desired end-state for a good dispute settlement may be applied by practical, and mutual self-defence under the support of a new AmericaJapan alliance. While the "offshore control" policy remains at its preliminary stage of growth, it appears that the Japanese security experts are gaining popularity and have been reviewed by an expert panel of the Okazaki Institute (Auer, 2013). Several of them form a part of the America-Japan strategic dialogue. 
A strategy is not identical to an operating plan, but it is more important to provide a Strategy in certain respects than a shelved plan for a specific circumstance. Consequently, the latest attempt to revise the Security Guidance is not a practical contingency effort, such as Taiwan, though a significant move towards upgrading and standardizing a concept of joint operations in which Japan and America are concerned. Finally, any bilateral partnership plan is realistic and appropriate to both parties. In Japan's case, preliminary improvement is to be made in standardizing security challenges until a genuinely combined plan to disrupt China or protect Taiwan can be dedicated. Second, Auer could claim that constant regular cooperation and joint activities between alliances are more critical than just a conceptual guideline or a tactical strategy to resolve a strategic problem. Acting shoulder to shoulder consistently for a mutually favourable target is the real power of every Partnership (Swaine et al., 2013). In close alignments with the Asian hands prominent in the new American government, such as Joseph Nye and Susan Shirk, Yasuhiro Matsuda's can be a complex moderate opinion.

Matsuda favours an equilibrium that preserves the coalitions wants alliances and states that former Asian countries with antagonistic ties with China-Taiwan, Vietnam, and India now aim to strengthen their position. He sees merit as long as he targets Chinese confusion rather than marking it as a hazard prematurely. Also, he finds challenging balance as a choice that can be done in Japan, claiming that if Japan alone follows the containment route, it would be the only loser. Matsuda (2012) believes that Japan's domestic discourse may move its support from a powerful shield against China and hence the alliance - an estimation that is in line with the prescription of Samuels's Goldilocks, in which the future of Japan is 'about correct' somewhere amongst the interaction with China and the reliable defence hedge between Japan and America Similarly objective is Matsuda's observation regarding Japan's connection to Taiwan. In his view, the Partnership between Taiwan and Japan is mainly one of the most stable in East Asia, but the present mild and stable Strait climate makes enhanced political links. It is unlikely to establish a more aggressive cross-stream atmosphere that Matsuda will strengthen Japan-Taiwan relations. This study's proof contradicts this argument since security and political relations between Taiwan and Japan seem to have improved dramatically during times of big cross-cutting tensions. With the public sentiment in Japan hardened than China and ever more supportive to Taiwan, it represents how much Japan is ready to gamble in Taiwan's relation. The key consequences of Matsuda's estimates for the alliance are that, as the largest member of the alliance, Japan is still in tremendous need of America to have high-level publicity for the pragmatic concerns.

\section{Conclusion}

Whereas Japan's ties with Taiwan also need to be seen as primarily beyond China's economic priorities and crisis management actors, the real change in Japan's foreign policy over the last two decades is an implication of balance-of-power interests in favour of Taiwan. It is subjective to the attribution approach to differentiate between the foreign policy priorities groups. For example, the Fishery Convention between Taiwan and Japan, signed in 2013, can be used as crisis management (Taiwan) and the balance of power (China). A suitable form of quantification is not available. The key is that Japan has taken big moves towards fostering the equilibrium of power preferences affecting Taiwan even in the age of Cross-Trait Approaching. While Taiwan and Japan atrophied the traditional de facto bureaucratic structure in 2012, in many ways, the Taiwanese lobster led by conservative LDP factions was bolstered by their opposition status over this time, with Japan/Taiwan finally establishing and influencing tactical relationships. In addition to codifying a modern Japanese diplomacy policy, the interaction 
between Japan and Taiwan has become the prime target of the Japanese-Taiwanese balance of power priorities.

The key priority of Taiwan under the Ma administrations was stable ties with China and rapprochement, however, its alliance with Japan was often seen by Taiwan as a significant and widespread means of maintaining diplomatic space from China-with Japan's major power balance interests directly in common - to provide Taiwan with continuing diplomatic space and de-facto sovereignty to escape Taiwan and Japan has been quite active in recent years in this primary target. There are also unpleasant truths in the world of international relations in the East Asia. America has failed to adopt a policy to protect its interests in Asia if it does not comply explicitly with those inconvenient facts. The fact of Japan's domestic desires in Taiwan is often part of a disturbing reality. However, as artificial standards are increasing, the standard of comfort just further deteriorates. China would have tough choices, which have mostly less than ideal consequences for the America role in the field, whether they will unify with Taiwan. The sole duty of America undoubtedly resides concerning its national interests. There are several other conceivable and also unexpected possibilities, such as a reunited China, in which the Taiwanese officials serve as mediators for China and Japan, as well as America and China as the major military allies, in which America mediates the reconciliation between Japan and China and a host of unforeseen grey and black swan scenarios. All this is considered as necessary for America to understand its partner's possibly divergent views (Japan) concerning Taiwan, which is most important for full functionality in an area that holds America's key interests in the region.

\section{Declaration of conflict of interest}

The author(s) declared no potential conflicts of interest(s) with respect to the research, authorship, and/or publication of this article.

\section{Funding}

The author(s) received no financial support for the research, authorship and/or publication of this article.

\section{References}

Andrew, J. \& Michael, d. (2020). U.S.- China feud over Coronavirus erupts at World Health Assembly. The New York Times. https://www.nytimes.com/2020/05/18/health/coronavirus-who-china-trump.html

Asahi, S. (2013). Abe cabinet approves National Security Council bill amid China tensions. http://ajw.asahi.com/article/behind_news/AJ201306070106

Auer, J. (2013). What do you call the SDF if not a military force? Sankei Shimbun: "Seiron" column, 7.

Ayumi, T. (2016). What's next for Japan-Taiwan relations. Council on Foreign Relations. https://www.cfr.org/blog/whats-next-japan-taiwan-relations

Benjamin, S. (2020). Japan should deepen defence/security cooperation with Taiwan. Debating Japan.

https://csis-website-prod.s3.amazonaws.com/s3fs- 
public/publication/DJ_Vol3_Issue\%203.pdf?7K4O7tCpUW4mU8A1c5QnmroeHS CgbzJw

Bonnie, S. (2017). What is the U.S. one China policy, and why does it matter? Center for Strategic \& International Studies. https://www.csis.org/analysis/what-us-one-chinapolicy-and-why-does-it-matter

Chan, K. (2020). U.S. should diplomatically recognize Taiwan: Bolton. Asia Times. https://asiatimes.com/2020/07/us-should-diplomatically-recognize-taiwan-bolton/

Copper. (1999). Taiwan: Nation-State or Province? Westview.

Douglas, M. (1970). The politics of Formosan Nationalism. University of California.

Edward, W. (2019, August 13). Waning of American Power? Trump struggles with an Asia in crisis. The New York Times. https://www.nytimes.com/2019/08/13/world/asia/trumpasia.html

Edward, W. (2020 August 17). U.S. Tries to Bolster Taiwan's status, short of recognizing sovereignty. Nytimes.com. https://www.nytimes.com/2020/08/17/us/politics/trumpchina-taiwan-hong-kong.html

Edward, W. \& Steven, L. (2020, July 25). Officials push U.S.-China relations toward point of no return. The New York Times. https://www.nytimes.com/2020/07/25/world/asia/uschina-trump-xi.html

Eleanor, A. (2020). China-Taiwan relations. Council on Foreign Relations. https://www.cfr.org/backgrounder/china-taiwan-relations

George, K. (1974). Formosa: Licensed revolution and the Home Rule Movement. University of Hawaii.

Grant, N. (2020). Japan should deepen defence/security cooperation with Taiwan. Debating Japan. $\quad$ https://csis-website-prod.s3.amazonaws.com/s3fspublic/publication/DJ_Vol3_Issue\%203.pdf?7K4O7tCpUW4mU8A1c5QnmroeHS $\underline{\text { CgbzJw }}$

Green, R. (2002). James McClain, Japan: A modern history. Norton

Hisahiko, O. (2005). Japan-U.S. alliance a guarantee for peace. Daily Yomiuri.

Jacobs, J. B. (2006). One China, diplomatic isolation and a separate Taiwan. In China's Rise, Taiwan's Dilemma's and International Peace (pp. 113-137). Routledge. https://www.taylorfrancis.com/chapters/edit/10.4324/9780203099841-16/one-chinadiplomatic-isolation-separate-taiwan-bruce-jacobs

Jacobs, J. B. (2012). Democratizing Taiwan. Brill.

Jacobs, J. B. (2013). Whither Taiwanization? The colonization, democratization and Taiwanization of Taiwan. Japanese journal of political science, 14(4), 567-586. https://doi.org/10.1017/S1468109913000273

Jim, M. (2018). Summary of the National Defence Strategy of The United States of America, sharpening the American military's competitive edge. https://dod.defense.gov/Portals/1/Documents/pubs/2018-National-Defense-StrategySummary.pdf

John, B. (2019). John Bolton: The scandal of Trump's China policy. The Wall Street Journal. https://www.wsj.com/articles/john-bolton-the-scandal-of-trumps-china-policy11592419564

Joseph, D. (2020). Navy sends another guided-missile destroyer through Taiwan strait. Stripes.com. https://www.stripes.com/news/pacific/navy-sends-another-guidedmissile-destroyer-through-taiwan-strait-1.632855

Kan, S. A., \& Morrison, W. M. (2014). U.S.-Taiwan relationship: Overview of policy issues. Congressional Research Service. https://sgp.fas.org/crs/row/R41952.pdf 
Kawashima, S. (2015). Assessing the Historic China-Taiwan summit and its implications for Japan. Nippon.com. https://www.nippon.com/en/column/f00035/

Khatoon, A., Rahim, N., Ali, B. (2018). A historical perspective of China's peaceful policies and its rise as world economic power. Liberal Arts and Social Sciences International Journal (LASSIJ), 2(1), 65-74. https://doi.org/10.47264/idea.lassij/2.1.8

Lawrence, S. V., \& Morrison, W. M. (2017). Taiwan: Issues for Congress. Congressional Research Service. https://fas.org/sgp/crs/row/R44996.pdf

Lindsay, M. (2019). U.S. military support for Taiwan: What's changed under Trump? Council on Foreign Relations. https://www.cfr.org/in-brief/us-military-support-taiwanwhats-changed-under-trump

Mark, P. \& Ramon, M. (1984). The Japanese Colonial Empire. Princeton University.

Mark, R. (2015). Taiwan Urges Japan to apologize for comfort women after South Korean deal. World Time. https://time.com/4164004/taiwan-japan-comfort-womenresolution/

Matsuda, Y. (2012). Japan-Taiwan relations in the new era. Paper presented for the 7th JapanTaiwan Dialogue for the New Era, Taipei, Taiwan.

Mukhtar, M., Sherazi, T. Z., \& Ahmad, R. (2020). Chinese traditional governing approach: An analysis from ancient to Mao Zedong politics. Liberal Arts and Social Sciences International Journal (LASSIJ), $\quad 4(2), \quad 441-452$. https://doi.org/10.47264/idea.lassij/4.2.34

Ryan, H. (2021). America's intensifying focus on Asia opens opportunities for strengthening US-Taiwan relations. Brookings. https://www.brookings.edu/blog/order-fromchaos/2021/09/08/americas-intensifying-focus-on-asia-opens-opportunities-forstrengthening-us-taiwan-relations/

Ryo, S. (2014). Japan-Taiwan relations since 2008: An evolving, practical, non-strategic partnership, in Jean-Pierre Cabestan and Jacques deLisle. Routledge.

Swaine, M. D., Mochizuki, M. M., Brown, M. L., Giarra, P. S., Paal, D. H., Odell, R. E., ... \& Ren, X. (2013). China's military \& the US-Japan alliance in 2030: A Strategic net assessment (p. 309). Carnegie Endowment for International Peace.

Sheerazi, T. Z., Khan, A., \& Khan, H. U. (2020). Great Water Wall in South China Sea: Maritime Designs of China under Mahan's Theory of Sea Power. Liberal Arts and Social Sciences International Journal (LASSIJ), 4(2), 278-293. https://doi.org/10.47264/idea.lassij/4.2.22

Tetsuo, K. (2015). The Japan-Taiwan fishery agreement: Strategic success, tactical failure? Asia Maritime Transparency Initiative. https://amti.csis.org/the-japan-taiwanfishery-agreement-strategic-success-tactical-failure/

Tsai, H. Y. C. (2009). Taiwan in Japan's empire-building: An institutional approach to colonial engineering. Routledge. 